\title{
ENDORSING SENSE OF IDENTITY FOR COLLEGE STUDENTS' ENGLISH LANGUAGE PERFORMANCE
}

\author{
Yuehong Wei \\ Li Zhang \\ Department of English, North China Electric Power University, Baoding, China \\ Email: wyh231@163.com
}

\begin{abstract}
APA Citation: Yuehong, W., \& Zhang, L. (2016). Teaching research of college students' sense of identity in regular class. English Review: Journal of English Education, 5(1), $149-158$
\end{abstract}

Received: 06-10-2016

Accepted: 11-11-2016

Published: 01-12-2016

\begin{abstract}
Triggered by the lack of students' sense of identity in English regular class effects their language achievement, this research aimed at developing a kind of teaching mode for building students' sense of identity with a series of teaching activities. Targeted at 55 nonEnglish major students for one semester, the experiment was to explain the effectiveness of this kind of mode in endorsing student's sense of identity. Here, the researcher used teaching observation and students' feedback to collect the data. It revealed that the kind of mode can help improve students' sense of identity, intrigue their interest, and improve their English learning efficiency.

Keywords: sense of identity, college English, regular class, English class, teaching research
\end{abstract}

\section{INTRODUCTION}

Sense of identity, also called identification is a kind of complicated mental phenomenon. Among researches about sense of identity in China, scholars usually interpret sense of identity as the concept of internalization or concept of imitation and regard it as the change of emotions, attitude and cognition (Wang, 1998). Currently, researches show that engineering major students are low in sense of identity and they have no sense of achievement or interest during English classes so that they are unable to meet the basic requirement of English class whether from the point of cognition, emotion or attitude. Especially for freshmen who are forced to learn English for College Entrance Examination, their attitude toward English learning have been changed since they feel less stressful when entering college. According students' sense of identity has been much lower and they have little confidence, therefore, they lack enthusiasm and sense of achievement. Besides, since the number of students has been much higher and teachers fail to supervise and guide each student just as teachers do in high school, students could not fully concentrate on classes. For some students, they can pass the CET4 by cramming for it, while some students just fail it. For teachers, they have the responsibility to guide students to solve this kind of problem.

Vygotsky(1978) held that the development of advanced cognitive function depends on the interaction between human and society and the negotiating relationship between language and other sociocultural products. That is to say, people's cognitive activities are mediated through the cultural products and symbols and 
are to be developed, which is the central part of Mediation. According to Lantolf and Thorne(2006), the Mediation in L2 learning refers to:1) the mediation in the social interaction with other (interpersonal mediation or other regulation); 2) the mediation by artifacts or object regulation; 3 ) the mediation through private speech as mediation by self or self-regulation.

The Zone of Proximal

Development(ZPD) refers to the distance between the learner's language level dependent on self and the level developed under the help of cooperative assistant (Lantolf \& Thorne, 2006).ZPD is adapted to the human cognitive development process and can guide the teaching. But it is difficult to be applied to the practice.

Scaffolding Theory refers to the cooperative behavior between any adult or child and experts or novice (Lantolf \& Thorne, 2007). Wertsch (1985) put forward that Scaffolding Theory is the interaction between peers or a collective unit. This theory combined with the ZPD can be applied to the teaching process and can guide the learners to develop their cognitive ability.

In this study, sense of identity is students' emotion and attitude towards English learning, which belongs to social identity. According to the theory of social psychology, sense of identity consists of recognition, emotion and attitude (Zhang \& Jin, 1996). Therefore, teacher should focus on the improvement of recognition, development of emotion and building of confidence when conducting teaching activities. Guided by social-cultural theory including the three main concepts introduced above, teachers should attach great importance to the role of English as bridge and platform, as well as the role of zone of proximal development.

\section{METHOD}

The subjects of the experiment are 55 freshmen of the second semester. Students are divided into the regular class according to their normal or poor performance despite the fact that some of them may get high grades by chance. Some of the students are of high learning motivation, while other students, and though with good knowledge in English, are of low motivation and lacking the sense of identity.

The teaching materials of the experiment are theNew Horizon College English, CET-4 Special Training Text Paper and English Vocabulary of New Oriental, and questionnaire of the teaching performance. English classes are twice a week and two class hours for each class. The experiment design includes the holding of the seminar about students' attitude toward English. After one week, teachers find that students are inactive and even indifferent towards classes and homework. After negotiation between teachers and students, the themes of the second seminar are about "is English learning important?", "what should we do during classes?", "how should we overcome the difficulties of English learning?", "do students have their learning target?" Teachers can assign some homework within students' reach, for instance, dictation with English explanation, dictation of CET-4 vocabularies which should be corrected every time by mutual correction among students or the selective correction by teachers; presentation of each unit, discussion on a certain topic which aims to lead students to learn new knowledge, build confidence and strengthen their sense of identity, English debate to inspire students' potential. In order to get a better interaction between students and teachers, the reflection journals are 
requested for twice. Most of them wrote the journal in Chinese and some of them wrote them in English. For the purpose of analysis in the research paper, all the reflection journals in Chinese have been translated into English (shown in Appendix I).

\section{RESULTS AND DISCUSSION}

Collecting data by written and oral feedback from students and monitoring students' learning outcomes by observation during classes.

During the seminar, some students think that teachers are too strict with them compared with the first semester and feel it hard to adapt to. Whatever purpose behind the words, it does cause a great responding among students. Teachers positively acknowledge the fact and lead students by posing the question that what's the consequence without any pressure. For this question, most students say that they only think about the great trouble left by heavy homework instead of its consequences. They hold that they are confused about the role of English in their future career and do not want to devote themselves to it. When asked about whether they want to pass CET-4 this semester, most students give a positive answer since they could only get their academic degree with the CET-4 certificate. In fact, some students are able to pass the exam by hard working while others are in great trouble. Given their current performance, whether students with good or poor English, there is a high possibility that they won't pass it.

After fierce discussion, students come to the conclusion that they will suffer great losses if they do not change their attitude towards English learning. They should know that they learn English for themselves instead of teachers. Both teachers and students are fulfilling their duties, one for teaching and another for learning.

After the discussion, students have changed their attitude and emotions. Students who are hard-working have been praised and students who are a little inactive have realize the consequence of their inappropriate behavior. It proves that self-adjustment of students is better than the push or the compulsory measures of teachers.

Homework should be within students reach. For instance, word dictation can give students great encouragement. Even though students only get several words right, they will be encouraged and feel that they can make further improvement. Some students talk with teachers that they find dictation is not that difficult and they are even anticipated for it. For presentation, students can get the topic they are interested in and get more exercise. After the accumulation of achievement, students can get comprehensive improvement.

For regular homework, students need to write 5-7 pages' words with A4 paper and teachers will check whether students have memorized those words by dictation. For some students who are unwilling to cooperate, teachers will take a flexible attitude. If you can memorize all words, it does not matter whether you write it or not. After two weeks' practice, some students require that they want to follow this kind of training and even insist on it for the whole semester. For teachers, they should provide a good platform and help students develop good learning habit. The basis for the development of sense of identity is that students have realized the vital role they have played in English learning.

English debate help students enjoy their time and enhance their confidence. Since it puts a high requirement on 
students' English ability, English debate is held on the end of each semester. While debate rules and relevant sentence structure will be told to students in advance so that they can make better preparation and know how to be logical. Students are positive but not confident about the debate. Debaters will be divided into two teams and the top debater of each team will give a conclusion after each team member expresses their own opinion in English separately. Debate relies on the clarity of words and logic of thinking. As the carrier of debate, English plays very significant role and acts as the tool for checking students' English learning. Some students are even surprised that they should debate in English and it has strengthened their confidence and sense of identity.

Students' written feedback (See Appendix I) shows that they have initially built their sense of identity and the reasons are as follows: 1 . Common efforts of both students and teachers. At first, some students felt it hard to adapt to teachers' teaching method or the change of teacher. And some teachers are not so strict with students that students regard English learning as a kind of recreation instead of an important way of gaining knowledge. But the joint efforts of teachers and students make English leaning more relaxed and enjoyable. Some students hold that they feel good about classes in this semester and gained a lot. 2. Effective selfadjustment. In the very beginning, some students hold negative attitude towards English homework. In spite of their unwillingness, students are forced to write English words. Gradually, they recognized that they have memorized some words. Though difficult, students feel it effective if they insist on writing word every day. 3. Establishment of sense of identity at the end of semester. Some students said that English classes give them a chance to express their views in English and intrigue their interest. Teachers' great responsibility help them won appraise from students. Helping students set the sense of identity is very important in the teaching process. Some activities are needed to be designed in improve it and let the students get some experience of to be good and a sense of achievement. Meanwhile letting the students selfmonitor their learning process and getting themselves in the class activities are equally important. The teacher should establish a good environment and guide the students with some interesting topics and set the proper steps for their learning.

It turns out that students should devote themselves to the classes. Otherwise, they will fail the expected outcome. Effective teaching activities can enhance student's cognition and consolidate their knowledge. With the improvement and achievement, students' sense of identity has been greatly intrigued. ZPD and Scaffolding can be applied in this teaching process and put the theory into practice and can be the basis of the teaching plan. It is necessary for the teacher to make a teaching plan following some psychological theory and provide a social interaction chances for students. Then students can benefit from the cognition development when they are be involved in the activities with some interaction between students and teachers or students and books,even students and some medias.

\section{CONCLUSION}

There are great numbers of excellent English learners in China, but college English teaching and learning 
face great difficulties. Dummy English has discourages us and most people of higher education regard English as the most difficult course. All of these shows that the shortage of sense of identity causes English learning are more difficult. Centered on sense of identity with the effective teaching activities and specific learning method, the research aims to help students build confidence and change their attitude towards English. Targeted at students with average English performance, all teaching activities and goals are designed for students which can help them improve their performance, strength their sense of identity and confidence. With qualitative study, the research has its own restrictions which are the narrow target of partial English learners. Therefore, more quantitative research could be done with the target of more excellent students and comparative study between regular class and advanced class.

\section{ACKNOWLEDGMENT}

This research was supported by "Fundamental Research Funds for the Central Universities (Grant\# 2016MS135) and the Excellent Youth Teacher

Supporting Project.

\section{REFERENCES}

Wang, J. (1998). The psychological process of social norm learning identity. Education Research,1, pp. 36-42.

Zhang, Z.,\& Jin, S.(1996). Social Psychology. Beijing: People's Education Press. Pp. 186-190.

Lantolf,J.P.,\&Thorne,S.L.(2006). Sociocultural Theory and the Genesis of Second Language Development. Oxford: Oxford University Press.

Qin, Lili., \&Dai Weidong. (2013). The Construction of Motivational Self System in College English Learning from the Aspect of Activity Theory. Foreign Language World. 6, pp. 23-31.

Lantolf. J. P.,\&Thorne, S. L. (2007). Sociocultural theory and second language learning. In $\mathrm{B}$. VanPatten\&J. Williams (Eds.),Theories in Second Language Acquisition(pp.201-

23).Mahwah,NJ:Lawrence Erllbaum Associates.

Wertsch,J. (1985). Vygotsky and the Social Formation of Mind[M].Cambridge: Harvard University Press. 


\section{Appendix}

1. Suggestion: After finish section A of each unit, teacher should require students to memory some translations. It could benefit both our study and exams. Teacher should dictate the words from section A and section B instead of checking the words from the PET4 book because in fact we are too busy to memory many. When explaining the text, it will be better if teacher could translate some long and difficult sentences or carefully explain in Chinese. Teacher should modify the essays according to the requirements of PET2 instead of PET4.

2. All the English lessons have been finished, and I have some inspiration for this term's learning. English learning has its' own tasty and most of student dislike it. In fact, it is not so boring like we have thought. Once doing well in the vocabulary, grammar, and practicing the oral English, listening, you will find it is easy than the Chinese. We practice the Chinese every moment, while do not have time to learn English. So we should have the confidence.

3. This term, the difficult of learning is down. And I felt more relaxed than last tern's, but it was a little nervous. The teacher's strict treatment made me realize that this is collage and the English was still important. This term, I enjoyed finished the work and also learned some new knowledge. Not only that, I fully used those knowledge in the CET4. Thanks the teacher's guide this term.

4. In a word, the teacher's guide is successes. As the college teacher, not only did she put pass the CET4 as the teaching goal, of course itwas not means important, she told us learnt English was important in our working, life and training the ability through the example of her life in America. Besides, the best part of my learning had been the change of thinking. The interested class and interaction with teachers made me think the English study is not so difficult and even is interesting. In the future, I will learn English continually even graduated because I should have the realize that learning English.

5. The whole term's learning makes me get progress and also learn some American culture. I am interested in learning English. And the teaching way and attitude fully meet my need. I think it was same as my senior English teacher because you are all so strict and have the sense of responsibility for the job. At the beginning, the class was a little quiet, but through the effort, the English learning was relax and interesting. And I learnt more knowledge. Wishing you the best of health and success, and I can make an improvement and get progress in my study.

6. First, I want to make self-examination. This semester, I cut class once and went to class late once, which I think are really impolite and irresponsible. As for English study, I feel just so and of course, my condition is not as good as in high school. However, considering that I am in university now, it is acceptable. In general, the state in which I feel about teacher you has been divided into three parts: good-badgood (the bad state refers to the time when you asked us to copy the words). Your teaching level is very high and your teaching is full of your own features. All in all, I think highly of your class. Finally, I wish teacher you the work of your heart and happy every day.

7. I think English classes this semester are pretty good, teacher is stricter than last semester and I have learnt a lot. Sometimes I was not that careful but teacher really taught well. For example, teacher spoke in English all the time and sometimes I could understand but sometimes could not. All in all, I made some progress. At the 
same time, I like some activities, like dramas before class, and debates. When having those, I felt very joyful. Nevertheless, my behaviors were not that good, my statements were few and my English was poor still.

8. I've been caught using my cell phone in the first class so I never did that again. Generally speaking, you are an excellent and responsible teacher. I felt really happy in your class. Wishes teacher you have students everywhere someday.

9. Your teaching style really differs from other teachers. At first, I think you were strict (maybe it was because the PET4 is coming). Then I gradually got used to the style and become outgoing.

10. In this semester, I have learnt a lot of extra-curricular knowledge. To some degree, this class is the most unforgettable. You have shown us some pictures you took in the US, which left me a profound impression. This class has told me what the US looks like. I believe that one day I may go and settle there. Thank you very much, my teacher.

11. This semester I worked harder than last semester to learn English and before the CET - 4I remembered a lot of words, and did some exercises. Your teaching methods fit in very well with us, which improves our enthusiasm of learning English. In my opinion, English learning is nothing more than listening, speaking, reading and writing. However, I feel we have little opportunity to speak in class. Even if I want to say something, words usually fail me. Besides, I think reading English articles works well, and remember the words requires daily accumulation.

12. This semester's English courses let me have a sense of fullness. Because the learning rhythm is a little tough, I felt a sense of pressure. I think the study did not seem that easy like last semester, but I take it more serious than last semester.

13. It seems as if I have never studied English after I enter my college. I often studied one or two days to prepare for the exams, but after the exams I would remember nothing. Therefore, I think I have learned almost nothing in English. But I promise I will make it up in the future.

14. I have learned a lot in English in this semester. I not only remembered a lot of words for TEM-4, but also gained much progress in listening and writing. However, due to the large amount of learning terms, I spared less time for English. As a result, my grades have showed this. The current English learning problem is after the TEM-4, there is no motivation for me to learn English. However, as long as I agree with English learning has a great benefit to my future life; I will generously input time and energy to learn English.

15. At the beginning of this term I feel not very adaptable for a new English teacher. Compared to last semester, more severe teacher teaching increased a lot of pressure, perhaps it was because we just wanted to take the examination of TEM-4.Teachers held us too tight, though from the point of view of the results, it indeed played a certain role. We did remember a certain number of words, and also did many papers. Although we cannot say how much progress has been made, but at least we keep the stability of the English level. Thank you for the whole year's hard work.

16.I have gained a lot through the half-term's learning. There are many interesting things in each class, especially some funny things that you have experienced in America. From my perspective, there is nothing can be compared with the happiness that I have gained in the sharing process though there are only some pictures and explanations. 
In my opinion, I think it is very relaxed in this term. As time going by, I think I can communicate with you more convenient. Due to lots of listening exercises, I have made great progress in it. What impressed me most was once I saw an English film with Chinese subtitles, I could understand the meaning of the film by seeing the scene and listening to the English words.

I do hope I can make more progress in English in the future. I wish teacher can lead a healthy and happy life.

17. To be honest, I couldn't fix well with your teach methods at first, because it was quite different from the last teacher's. But I can adapt to it gradually and I think it is good to teach us strictly. May health and happiness be with you.

18. Generally speaking, I have gained a lot, not only some English knowledge, but also some foreign customs and methods of dealing with things during the one year English learning in the college. Compared with boring grammars, college English is more interesting. What's more, I have made a great progress in listening. At first, I would lose interest in studying and miss myself with low efficiency because of mandatory requirements.

19. I really hope that teacher can strengthen communicating with all of us, but not just some of us and stand in the perspective of students. I would like to have a teacher who is not only our teacher, but also our friend who is not serious. Besides, thank you very much to teach us authentic English knowledge and classes which can help us learn a lot about America and English directly.

20. Thank you very much for your tolerate and care in half of the year. I think teacher is very kind and gentle and care about our learning at the same time. However, somehow I feel that our teacher is a bit serious to us. Actually, in terms of learning, I haven't made too much progress. I think it's mainly due to my own fault and I pay little attention to English studying so that my English is worse and worse now.

21. In my opinion, I think that the English classes of this term are quite different from last term. Compared with last term, we can answer more questions in class, learn knowledge more effective and think independently for longer time. However, it's really a pity that we don't have our words listening anymore which make us lazier after classes. Actually, I think all these are because of me, my will-power is not strong enough and I am not hard-working. I really hope that teacher can explain the exercises to us in the following days.

22. At first, thank you very much for your teaching of this term. I have gained a lot this term, not only knowledge, but also some foreign cultures and life styles in your class. I feel regret that I pay little attention to English this term. In fact, I couldn't fix well with the new teaching method, but we can see that you have invested a lot on us. So I feel really sorry for my slight. From my perspective, I hope we can begin from some practical exercises.

23. For loose people like us, it's really effective to teach us strictly. Actually, each day a list of words can remind us of learning English more. However, I can't understand what teacher means sometimes though teacher taught us a lot in classes, so do other classmates. So I hope teacher can translate and explain some difficult sentences to us. What I regret most was that I didn't work hard before the CET-4, so I didn't get good grades and I had no idea whether I could pass the CET-4.

24. I think teacher Wei is very serious and responsible in English teaching of this term, but teacher isn't lack of humor so that our class is lively compared with other 
classes. What's more, the way of words test is really special because we cannot predict which way our teacher will use to test us------teacher will read tell us the words' English explanations to test us, but not the Chinese meanings. In fact, I always got up late so that I would be late for classes and I didn't receive my classmates' messages. In today's class which is also the last class of this term, we know a lot about your experiences in America. At last, I hope that you can meet your classmates in the future.

25. Our teacher is really a good teacher. I feel teacher is very considerate and patient in half of a year. I like the American life which teacher has told us very much and I really look forward to this kind of life. However, I also correct the wrong mind that America is better than China in every aspect because I realize that we have our own life styles and we also can make great efforts. There is no need for us to admire other countries blindly. Actually, I am not a good student because I didn't come to have classes for many times. But I was moved when teacher encouraged and persuaded me with patience. At last, thank you very much!

26. I think you are very good. I like the debate competition very much. You teach us very seriously. It makes me keep up with my English. I think being serious is very important.

27. I don't know how your feeling is but I think you feel that being very responsible for us may be idealistic. Don't worry. Just hold on to it. Perhaps you could do everything perfectly. But I think you could do everything better. Don't blame yourself. It's our fault. Our attitudes make us study not so great.

28. Very good!

English is very perfect! I will study English hardly.

29. While learning foreign language is boring sometimes I think English learning is useful, not only can it provide us with grace but let us relax. I think our teachers teaching is very interesting, but I think we should pay more attention to our textbook only by learning more about textbook can we get good grades. 


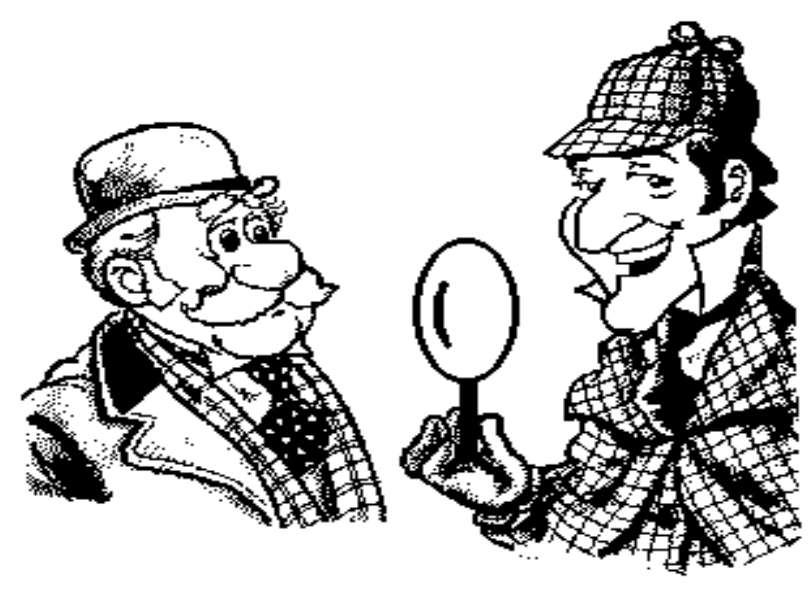

\section{Sherlock Holmes and Watson}

Sherlock Holmes and Dr Watson went on a camping trip. After a good meal and a bottle of wine they lay down for the night, and went to sleep. Some hours later, Holmes awoke and nudged his faithful friend awake. "Watson, look up at the sky and tell me what you see." Watson replied, "I see millions and millions of stars." "What does that tell you?" Holmes questioned. Watson pondered for a minute. "Astronomically, it tells me that there are millions of galaxies and potentially billions of planets. Astrologically, I observe that Saturn is in Leo. Horologically, I deduce that the time is approximately a quarter past three. Theologically, I can see that God is all powerful and that we are small and insignificant. Meteorologically, I suspect that we will have a beautiful day tomorrow. What does it tell you?" Holmes was silent for a minute, then spoke. "Watson, you retard. It tells me that some bastard has stolen our tent!"

(Source: http://www.study-express.ru/humour/funny-stories.shtml, picture: $w w w . g o o g l e . c o . i d)$ 